\title{
Erratum to: Estimating the Speed of an Integrated Wireless Network for Transportation Applications
}

\author{
N. Bogdanov*, A. Ancans, K. Martinsons, and E. Petersons \\ Riga Technical University, Riga, LV_1019 Latvia \\ *e-mail: Nikolajs.Bogdanovs@rtu.lv \\ Submitted November 14, 2019; accepted for publication November 14, 2019
}

DOI: $10.3103 / \mathrm{S} 0146411619050080$

On page 274, the name of the second author should read A. Ancans.

The original article can be found online at htps://doi.org/10.3103/S0146411614050046 